\title{
An unusual case of gout
}

\author{
Thomas Paul Jack Wolfenden, ${ }^{1}$ Jenny Jackson ${ }^{2}$
}

1 Department of Medicine, East Sussex Healthcare Trust, Hastings, UK

${ }^{2}$ East Sussex Healthcare Trust, Hastings, UK

\section{Correspondence to}

Dr Thomas Paul Jack

Wolfenden,

thomaswolfenden@doctors. org.uk

Accepted 13 March 2014

\section{DESCRIPTION}

A 73-year-old man was admitted with acute chest pain, associated nausea, clamminess and shortness of breath. In addition he reported lethargy, arthralgia and swelling of knee and wrist joints.

Relevant medical history included infective endocarditis in 1999 with subsequent tissue aortic valve replacement and coronary artery bypass graft (CABG). A further CABG in 2009 was complicated by a sternotomy wound infection.

Initially the patient was treated as per ACS protocol, serial troponins were not significant and pain continued.

Several days into the admission a fluctuant swelling became apparent on the sternum (figure 1), the patient became systemically unwell and a concurrent

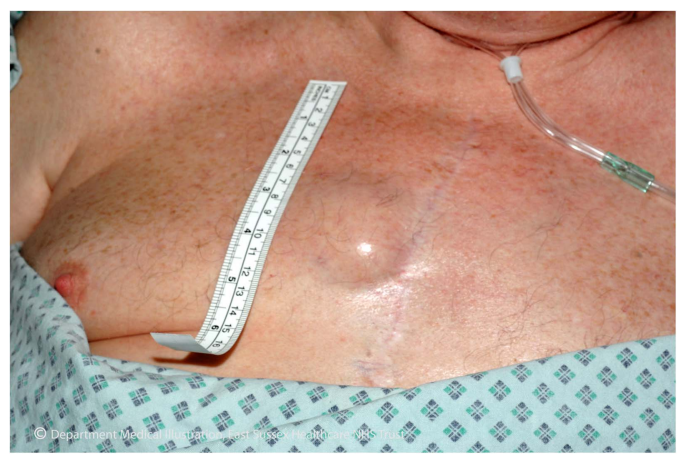

Figure 1 A photo of the fluctuant anterior chest wall mass.

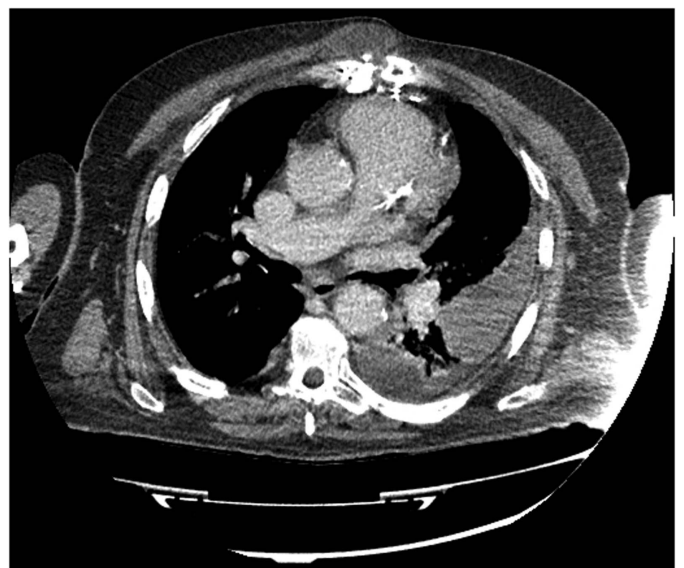

Figure 2 An axial CT slice of the chest showing the anterior chest wall mass. rise in inflammatory markers was observed (C reactive protein 157 and white cell count 12.5).

Concerned that there was an internally communicating abscess a CT was performed (figure 2). This revealed a cystic mass measuring $13.8 \times 42 \times 40 \mathrm{~mm}$ immediately anterior to the mid sternum.

Needle aspiration showed turbid yellow fluid. Microscopy revealed an aseptic fluid with large quantities of monosodium urate crystals. Serum urate levels were elevated at $649 \mu \mathrm{m} / \mathrm{L}$. Further aspirates from both knees confirmed polyarticular gout.

The patient was started on a course of colchicine, his symptoms improved significantly and we continued his long-standing allopurinol prescription.

\section{Learning points}

- Gout is a common condition effecting $14 / 1000$ people in the UK. ${ }^{1}$ It normally effects synovial joints but can affect non-synovial joints.

- There are a large number of differentials which can cause a systemic inflammatory response.

- The therapeutic goal of management should be to reduce serum urate concentrations to below $360 \mu \mathrm{m} / \mathrm{L}$. Allopurinol is the most effective agent in achieving a reduction in serum urate levels. It can be prescribed with colchicine concurrently even if the patients' joints are active and if the patient is allopurinol naive. ${ }^{23}$

Acknowledgements Dr Sathis Kumar, Consultant in charge of patients care. Dr Edward Henderson, Consultant in Rheumatology for his opinion and management of the patient.

Contributors Case written, images collected and consent gained by TPJW. Case also written by JJ.

Competing interests None.

Patient consent Obtained.

Provenance and peer review Not commissioned; externally peer reviewed.

\section{REFERENCES}

1 Mikulus TR, Farrar JT, Bilker WB, et al. Gout epidemiology: results for the UK general practice research database, 1990-1999. Ann Rheum Dis 2005:64:267-72.

2 Taylor TH, Mecchella JN, Larson RJ, et al. Initiation of allopurinol at first medical contact for acute attacks of gout: a randomized clinica trial Am J Med 2012;125:1126-34

3 Khanna D, Fitzgerald JD, Khanna PP, et al. 2012 American College of Rheumatology guidelines for management of gout. Part 1: systematic nonpharmacologic and pharmacologic therapeutic approaches to hyperuricemia. Arthritis Care Res 2012;64:1431-46. 
Copyright 2014 BMJ Publishing Group. All rights reserved. For permission to reuse any of this content visit http://group.bmj.com/group/rights-licensing/permissions.

BMJ Case Report Fellows may re-use this article for personal use and teaching without any further permission.

Become a Fellow of BMJ Case Reports today and you can:

- Submit as many cases as you like

- Enjoy fast sympathetic peer review and rapid publication of accepted articles

- Access all the published articles

- Re-use any of the published material for personal use and teaching without further permission

For information on Institutional Fellowships contact consortiasales@bmjgroup.com

Visit casereports.bmj.com for more articles like this and to become a Fellow 